\title{
POLUIÇÃO POR NANOPARTÍCULAS, RESPONSABILIDADE PENAL AMBIENTAL E PRINCÍPIO DA LEGALIDADE: REFLEXÕES ACERCA DA COMPLEMENTAÇÃO DA NORMA PENAL EM BRANCO DA LEI DE CRIMES AMBIENTAIS
}

\author{
NANOPARTICLE POLLUTION, ENVIRONMENTAL CRIMINAL LIABILITY AND \\ LEGALITY PRINCIPLE: REFLECTIONS ON THE COMPLEMENTATION OF THE \\ UNREGULATED CRIMINAL NORM IN ENVIRONMENTAL CRIMES ACT
}

\author{
Mateus de Oliveira Fornasier ${ }^{*}$ \\ Maiquel Ângelo Dezordi Wermuth ${ }^{* *}$
}

\begin{abstract}
RESUMO: este artigo aborda o tema da responsabilidade penal ambiental decorrente da poluição por nanopartículas face às insuficiências que a Lei dos Crimes Ambientais (Lei $n^{0}$ 9.605/1998) apresenta diante da complexidade que a questão suscita - o que se revela, particularmente, no fato de que, por se configurarem como normas penais em branco, os artigos 56 e seguintes da Lei em comento exigem complementação por outras fontes. Contudo, ainda não há no Brasil qualquer espécie normativa que regulamente o risco nanotecnológico, o que provoca o seu problema de pesquisa: há alguma possibilidade de que dita complementação se dê por meio de normas proferidas por outros órgãos, diversos do Poder Legislativo, como, por exemplo, as agências estatais regulamentadoras ou até mesmo órgãos não-estatais que emergem no pluralismo jurídico global atual? As hipóteses construídas ao longo do texto não descuidam do fato de que permitir a complementação das normas penais em branco pelas vias mencionadas pode representar uma intolerável flexibilização de garantias fundamentais asseguradas ao cidadão por um modelo de Direito Penal típico de um Estado Democrático de Direito - particularmente no que se refere ao princípio da legalidade. Objetiva-se, com isso, refletir a respeito da própria efetividade da tutela penal ambiental diante do cenário de degradação pela liberação indiscriminada de nanopartículas, demonstrando-se que, nesses casos, a proteção ambiental poderia ser alcançada em graus mais elevados de efetividade por meio de medidas civis, administrativas e penais alternativas, reafirmando, reflexamente, a ideia da subsidiariedade do exercício do jus puniendi estatal.
\end{abstract}

PALAVRAS-CHAVE: Meio ambiente. Nanotecnologias. Tutela penal. Norma penal em branco.

ABSTRACT: This article addresses the issue of environmental criminal liability related to pollution by nanoparticles, faced to the shortcomings that Environmental Crimes Act (Brazilian Law \# 9.605/1998) presents when faced to the complexity raised by this question - which is revealed, particularly, in the fact that, being configured as unregulated criminal norm, article 56 and following of the mentioned Act require supplementation by other sources. However, there is still no rules in Brazil that address nanotechnology risk, which evokes this research problem: is there any

\footnotetext{
* Doutor em Direito Público (Unisinos, Brasil). Professor do Mestrado em Direitos Humanos da Universidade Regional do Noroeste do Estado do Rio Grande do Sul (Unijuí, Brasil). Advogado. E-mail: mateus.fornasier@unijui.edu.br

** Doutor em Direito Público (Unisinos, Brasil). Professor do Mestrado em Direitos Humanos da Universidade Regional do Noroeste do Estado do Rio Grande do Sul (Unijuí, Brasil) e da Graduação em Direito pela Universidade do Vale do Rio dos Sinos (Unisinos, Brasil). Advogado.E-mail: madwermuth@gmail.com
} 
possibility for this complementation through norms elaborated by other bodies, diverse from Legislative branch - i.e. the regulatory state agencies or even non-governmental institutions that emerge in today's global legal pluralism? Hypotheses presented throughout the text do not neglect the fact that enabling the completion of unregulated criminal rules by the aforementioned legal pathways may represent an intolerable ease against fundamental guarantees provided to citizens by a pattern of Criminal Law typical of a Democratic State under the rule of law - particularly with regard to the legality principle. The purpose is, therefore, to reflect about the very effectiveness of environmental criminal law before degradation scenario resulting from indiscriminate release of nanoparticles, demonstrating that, in such cases, environmental protection could be achieved at higher levels of effectiveness through civil, administrative, and criminal alternative penalties, reaffirming, reflexively, the idea of subsidiarity of State's jus puniendi.

KEYWORDS: Environment. Nanotechnologies. Criminal Law. Unregulated criminal norm.

\section{INTRODUÇÃO}

Este artigo objetiva analisar a legislação penal ambiental brasileira, particularmente o tipo penal descrito no artigo 56 e seguintes da Lei nº 9.605/1998 (Lei de Crimes Ambientais), no que tange à incriminação de condutas lesivas mediante más práticas industriais e comerciais relacionadas às nanopartículas e processos de fabricação que envolvam nanotecnologias. $\mathrm{O}$ problema de pesquisa que orienta o texto pode ser sintetizado na seguinte objeção: em face da eventual criminalização da poluição ambiental por nanopartículas, considerando-se os artigos 56 e seguintes da Lei de Crimes Ambientais como normas penais em branco, de que forma se poderia conceber uma base normativa para sua complementação, já que ainda não há, no Brasil, qualquer espécie normativa que regulamente o risco nanotecnológico?

Parte-se da hipótese de que normas proferidas por outros órgãos que não o Legislativo (agências regulamentadoras, órgãos não-estatais que emergem do pluralismo jurídico global, etc.) apresentam alternativas para a complementação das normas penais em branco contidas na referida Lei, eis que, frente à ausência de qualquer normatização direta das nanotecnologias no Brasil, e sendo premente a necessidade de regulamentação do risco nanotecnológico, se faz indispensável esta complementação. No entanto, não se descuida do fato de que, se por um lado, essa proteção em face de um risco (negativamente consequentes do emprego de nanotecnologias) representa uma garantia ao cidadão, por outro, pode representar um outro risco, qual seja, a flexibilização de garantias fundamentais asseguradas por um modelo de Direito Penal típico de um Estado Democrático de Direito.

Num primeiro momento, este artigo expõe dados científicos relacionados ao risco nanotecnológico para a saúde humana e o meio ambiente. Analisa-se o que são as nanotecnologias, 
traçando-se logo após um breve histórico do seu desenvolvimento, para enfim apresentar dados consistentes de pesquisas científicas para se demonstrar a nocividade e o risco para a saúde humana que a liberação e o uso indiscriminado de nanopartículas acarretam.

Já num segundo momento busca-se definir e discorrer criticamente acerca da norma penal em branco e da sua presença no art. 56 e seguintes da Lei de Crimes Ambientais, conectando-a às problemáticas da poluição por nanopartículas em um contexto de expansão do Direito Punitivo e dos riscos que esta técnica legislativa representa para os direitos e garantias fundamentais do acusado da prática de tais condutas. Para isto, analisa-se o que a doutrina propõe acerca da chamada norma penal em branco.

Por fim, debate-se sobre a hipercomplexidade e a policontexturalidade atuais, demonstrando-se a impossibilidade estatal em regular áreas muito específicas da ciência e da tecnologia. Isto desafia a dogmática jurídica tradicional, pois um problema pragmático (regulação efetiva do risco nanotecnológico) estanca suas vias sintáticas (necessária adequação constitucional do Direito Penal) e semânticas (significação do princípio da legalidade em sentido estrito). É também apresentada, para ilustrar esse impasse, a International Organization for Standardization (ISO) e sua capacidade de regulação de tal matéria, maior que a do próprio Estado em suas vias tradicionais.

\section{DANOS À SAÚDE HUMANA E AO MEIO AMBIENTE EM RAZÃO DA DISPERSÃO DE NANOPARTÍCULAS E DA EXPOSIÇÃO A ELAS}

Um nanômetro (nm, em sua abreviatura) é a bilionésima parte do metro (1 x $\left.10^{-9} \mathrm{~m}\right)$, ou seja, 0,000000001 m. Para ser estabelecido um comparativo entre esta medida e tamanhos comuns no cotidiano, apresenta-se uma lista sintética:

- um fio de cabelo humano tem cerca de 50.000 nanômetros;

- a célula de uma bactéria tem cerca de algumas centenas de nanômetros;

• os chips comercializados em 2004 têm padrões menores que 100 nanômetros;

- as menores coisas observáveis a olho nu têm cerca de $10.000 \mathrm{~nm}$;

- 10 átomos de hidrogênio, alinhados, perfazem 1 nanômetro (FEYNMAN, 2004, p. 27).

Pode-se traçar uma pequena cronologia dos fatos mais importantes ligados ao desenvolvimento das nanotecnologias citando-se um esquema traçado por Oswaldo Alves, conforme se observa abaixo:

Em 1974, Norio Taniguchi cunhou o termo “nanotecnologia”, [para] máquinas que tivessem níveis de tolerância inferiores a um mícron $(1000 \mathrm{~nm})$. [Também podem ser 
citados] o trabalho de Gerd Binnnig e Heinrich Rohrer, criadores do microscópio eletrônico de tunelamento [...] em 1981; a descoberta dos fulerenos ${ }^{1}$, por Robert Curl, Harold Kroto e Richard Smalley, em 1985; a publicação do livro de Eric Drexler, Engines of Creation, que popularizou efetivamente a nanotecnologia. [...] O feito de Donald Eigler, [...] escrever o nome IBM, em 1989, com átomos individuais do elemento xenônio e a descoberta dos nanotubos de carbono, feita por Sumio Iijima, no Japão, em 1991. Tais descobertas, aliadas às perspectivas que admitiam a nanotecnologia como "uma nova revolução científica”, [...] levaram a administração de Clinton, então presidente dos Estados Unidos, a lançar, em 2000, no California Institute of Technology, a National Nanotechnology Initiative, [com] investimentos da ordem de U\$ 495 milhões [...] (FEYNMAN, 2004, p. 27).

O investimento estadunidense desencadeou a montagem de vários outros programas nacionais ambiciosos ligados à área (iniciando-se pela Comunidade Europeia e pelo Japão), em razão da percepção de que poderia ser significativa, num futuro próximo, para os países industrializados desenvolvidos (ou em desenvolvimento) - sendo que, entre 1997 e 2002, agências governamentais de todo o mundo reportaram um crescimento nos investimentos da ordem global de cinco vezes em pesquisa e desenvolvimento em nanotecnologias (FEYNMAN, 2004, p. 27).

Já são comercializados no mundo todo cosméticos e produtos de higienização doméstica, principalmente, envolvendo substâncias ou processos obtidos e realizados a partir do uso das nanotecnologias. Aliás, o próprio processo produtivo com a utilização de nanotecnologias pode trazer consequências bastante degradantes para a saúde do trabalhador diretamente envolvido.

[...] nunca ocorreu na história, o contato dos seres humanos, com nanomateriais sintéticos de elevada pureza, concentração, complexidade ou funcionalização, tornando a síntese, manipulação, manuseio, estocagem, estabilização, incorporação e o uso dos nanomateriais em um assunto de extrema complexidade, ainda não completamente estudado em sua profundidade, tempo e multidisciplinariedade necessária (SILVA, 2008, p. 14).

Os riscos da exposição do trabalhador às externalidades da produção envolvendo nanotecnologia têm sido objeto de sérias pesquisas na Europa já há alguns anos - por exemplo, o relatório da Royal Society and Academy of Engineering, Nanoscience and nanotechnologies: opportunities and uncertainties (2004), em que se elencam possibilidades de contaminação nas etapas de produção, transporte, armazenamento e tratamento de resíduos. Ademais, ao adentrar de forma difusa no meio ambiente natural, as nanopartículas residuais poderiam contaminar as águas, ser transportadas pelas correntes de ar, instalar-se nos alimentos, afetando o trabalhador não apenas no ambiente de trabalho, mas também em sua dimensão de consumidor (THE ROYAL SOCIETY, 2004).

\footnotetext{
${ }^{1}$ Fulerenos são novas formas de organização molecular do carbono, de fórmula $\mathrm{C}_{60}$ e $\mathrm{C}_{70}$. Sua descoberta (ou, melhor dizendo, seu desenvolvimento) permitiu a organização dos nanotubos, os quais já evoluíram para as nanoesponjas. (ALVES, Oswaldo. Nanotecnologia, nanociência e nanomateriais: quando a distância entre presente e futuro não é apenas questão de tempo. Revista Parcerias Estratégicas, Brasília, n. 18, p. 23-40, 2004, p. 30-31).
} 
O diminuto tamanho e a elevada energia superficial seriam as principais características das nanopartículas, o que faria com que se tornassem muito facilmente absorvidas pelos organismos (MAYNARD, 2005). Estudos têm sido feitos em relação aos efeitos dos resíduos da produção nanotecnológica nos diversos sistemas funcionais orgânicos humanos. Já se confirmou a presença de nanopartículas na pele, no trato respiratório, nos sistemas digestivo, nervoso, linfático e excretor, na circulação sanguínea, no leite materno, nos músculos e na placenta (OBERDORSTER; OBERDORSTER; OBERDORSTER, 2005, p. 836-838). Os principais meios de exposição citados nos estudos foram o consumo de água e alimentos, o acúmulo de nanorresíduos em roupas usadas e os sistemas de drug delivery.

Com a contaminação do organismo pelas nanopartículas, várias reações complexas e interações biológicas, físicas e químicas podem ocorrer - o que pode vir a desencadear processos de defesa celular (UNITED STATES ENVIRONMENTAL PROTECTION AGENCY, 2007, p. 54). Em relação aos possíveis efeitos nocivos causados às células do trato respiratório (em especial pulmonar), já foram descritos mecanismos de oxidação celular, o que levaria à sua destruição (NEL; XIA; MADLER; LI, 2006). Já no sistema circulatório, as nanopartículas podem causar trombose e parada do sistema cardiovascular em razão da obliteração do fluxo sanguíneo nas veias e artérias (SILVA, 2008, p. 29). A resposta cardiopulmonar à exposição às nanopartículas varia de acordo com as características do indivíduo exposto (idade, situação socioeconômica, configuração genética, doenças pré-existentes) (DONALDSON; BORM, 2007), mas pode ser resumida nas seguintes possibilidades: geração de espécies de oxigênio reativo, estresse oxidativo, perturbação mitocondrial, inflamação, absorção por meio do sistema retículo-endotelial, desnaturação e degradação de proteínas, absorção nuclear (celular), absorção pelo tecido nervoso (neurônios), perturbação na função de fagocitose, disfunção endotelial, efeitos na coagulação sanguínea, geração de neoantígenos, ruptura na tolerância imune, alteração no ciclo de regulação celular, danos ao DNA (inclusive alguns relacionados ao câncer).

Os nanomateriais mais comuns encontrados em produtos postos à venda no mercado mundial são compostos à base de prata, de carbono, de titânio, de silício e de zinco - mas as propriedades de tais materiais em nanoescala diferem em muito daquelas que apresentam quando tais substâncias se encontram em partículas maiores (FIORINO, 2010): a superfície de contato das nanopartículas em relação à sua massa é muito maior, o que as torna muito mais reativas; as propriedades ópticas, magnéticas e elétricas são muito diferentes daquelas quando estão na forma convencional; sua capacidade de se integrar no sistema biológico, alterar o metabolismo celular e se evadir dos mecanismos do sistema imunológico dos seres vivos também já são retratadas na ciência. 
Paralelamente a este grande risco, contudo, observa-se grande variedade de produtos postos em circulação, para consumo, contendo nanotecnologia. O Project on Emerging Nanotechnologies (NANOTECHNOLOGY, [201-a]) já lista cerca de 1.317 produtos no seu rol online, produzidos por 587 empresas localizadas em cerca de 30 países - tendo havido, entre os anos de 2006 e 2009, um aumento de cerca de 379\% neste número (FIORINO, 2010, p. 12). A maior das categorias listadas se refere a produtos do ramo de saúde e fitness (738 produtos), seguida pela categoria “casa e jardim” (209 produtos), “automotivos” (126 produtos), alimentos e bebidas (105 produtos), cross cutting (82 produtos), eletrônicos e computadores (59 produtos), appliances (44 produtos) e produtos para crianças (30 produtos) (NANOTECHNOLOGY, [201-b])

O risco decorrente das decisões tomadas em sociedade permeia todos os setores. Em especial, nota-se este fato na crescente colocação em circulação e no consumo de produtos e serviços nanodesenvolvidos, sem que haja o respeito a normas específicas para regulá-los. Urge, assim, a necessidade de normatização dessa produção, com o estabelecimento de padrões normativos minimamente eficientes, dotado de fundamentações capazes de fornecer parâmetros mínimos para que a colocação de produtos desse tipo, no mercado, seja razoavelmente segura numa sociedade de crescente complexidade. Deve-se, assim, pressupor um sistema normativo também mais complexo.

Há pouquíssimos instrumentos normativos em vigor, atualmente, no Brasil, que versam, de alguma forma, sobre nanotecnologias (para além de algumas normas técnicas da ABNT versando sobre as medidas, o significado dos termos ligados a nanotecnologias e outras adjacências). Por exemplo, o Decreto $\mathrm{n}^{\circ}$ 6.112/2007, o qual promulga o Acordo de Cooperação Científica e Tecnológica entre o Governo da República Federativa do Brasil e a Comunidade Europeia, celebrado em Brasília, em 19 de janeiro de 2004 (o “Artigo IV” do referido Pacto estabelece que uma das áreas das atividades de cooperação entre as Partes seriam as micro e nanotecnologias) (BRASI, 2007); a Convenção Coletiva de Trabalho FETQUIM-CUT, modificado pelo “Termo Aditivo” de 2012/2013, cuja “Cláusula Oitava” institui que “a CIPA, o SESMT e os trabalhadores terão ainda acesso a informações sobre riscos existentes à sua saúde e as medidas de proteção a adotar” (FEDERAÇÃO DOS TRABALHADORES DO RAMO QUÍMICOS DA CUT DO ESTADO DE SÃO PAULO, 2012); e a Portaria $n^{\circ}$ 245, de 5 de abril de 2012, do Ministério da Ciência, Tecnologia e Inovação (BRASIL, 2012a), que institui o Sistema Nacional de Laboratórios em Nanotecnologias (SisNANO), sendo a integração ao SisNANO regulamentada pela Instrução Normativa $^{\circ}$ 2, de 15 de junho de 2012, do mesmo Ministério (BRASIL, 2012b). 
Apesar dessas experiências, contudo, ainda não está vigorando, no Brasil, uma legislação propriamente dita regulando o desenvolvimento (e o risco) nanotecnológico. Mas já se encontra em trâmite o Projeto de Lei da Câmara $n^{0}$ 5.133/2013, cujo escopo é regulamentar a rotulagem de produtos contendo nanotecnologia. Esse Projeto ainda não foi apreciado por qualquer Comissão da Câmara dos Deputados, dado o caráter extremamente recente de sua proposição (SARNEY FILHO, 2013).

Várias tentativas por parte do Legislativo Federal brasileiro já intentaram regular o risco nanotecnológico - todas arquivadas em razão, principalmente, da redundância normativa (ou seja: expunham, nos seus textos, dispositivos já existentes em outras leis vigorantes). Pode-se observar o fenômeno da redundância desnecessária que eiva a elaboração de Projetos de Lei que intentaram (de modo malsucedido) regular o risco nanotecnológico no Brasil ao se analisar os trâmites das seguintes Proposições, já arquivadas:

- $\quad$ Projeto de Lei da Câmara n 5.076/2005, o qual pretendia dispor acerca de pesquisa e uso da nanotecnologia no Brasil. Pretende, também, tal projeto, criar uma Comissão Técnica Nacional de Nanossegurança (CTNano), instituir um Fundo de Desenvolvimento de Nanotecnologia (FDNano), entre outras disposições pertinentes (DUARTE, 2005). Esse projeto se encontra arquivado desde 28 de novembro de 2008 (BRASIL, 2008).

- Projeto de Lei do Senado $n^{0}$ 131/2010, que se destinava a instituir o dever dos fornecedores de informar ao consumidor (em embalagens e material publicitário) o conteúdo nanodesenvolvido de seus produtos. Intentava fazê-lo mediante alterações em dois diplomas normativos - o Decreto-Lei no 986, de 21 de outubro de 1969, que institui normas básicas sobre alimentos, e a Lei ${ }^{0}$ 6.360, de 23 de setembro de 1976, que dispõe sobre a vigilância sanitária a que ficam sujeitos os medicamentos, as drogas, os insumos farmacêuticos e correlatos, cosméticos, saneantes e outros produtos, e dá outras providências, para determinar que rótulos, embalagens, etiquetas, bulas e materiais publicitários de produtos elaborados com recurso à nanotecnologia contenham informação sobre esse fato (VIANA, 2010). Esse Projeto está arquivado desde $1^{0}$ de agosto de 2013 (BRASIL, 2013).

A fim de não se ilustrar um vácuo normativo específico no que tange à matéria risco nanotecnológico, apresenta-se a mais recente tentativa do Poder Público em fazê-lo: a Portaria $\mathrm{n}^{\circ}$ 1.358 da Agência Nacional de Vigilância Sanitária, de 20 de agosto de 2014 (BRASIL, 2014), ato normativo administrativo que visa criar um comitê interno relativo às nanotecnologias - formado 
por representantes oriundos das mais variadas áreas industriais que se valem do conhecimento nanotecnológico (e.g. farmácia, indústria de cosméticos, toxicologia, etc.). Esse comitê estaria apto para coordenar a elaboração de normas regulatórias das práticas nanotecnológicas no Brasil (além de outras atribuições correlatas), e possui um limite de 12 (doze) meses para concluir o trabalho.

Em outras palavras, não há, no Brasil, qualquer norma estatal atual que estabeleça limites para a manipulação ou liberação, no ambiente, de substâncias contendo nanopartículas, nem para processos de fabricação que envolvam nanotecnologia. Aliás, mesmo quando da entrada em vigor da eventual norma da Anvisa que estabelecerá padrões para disciplinar o risco nanotecnológico no Brasil, estar-se-á diante de uma situação em que um órgão do Poder Executivo (e não o Legislativo) legisla no estabelecimento de crimes. Isto prejudica - e muito - a repressão de crimes ambientais no Brasil, eis que os artigos 56 e seguintes da Lei n ${ }^{\circ} 9.605$ de 1998 (Lei de Crimes Ambientais), ${ }^{2}$ os quais tratam da poluição por substâncias nocivas à saúde humana ou ao meio ambiente, exigem a regulamentação por leis ou outras espécies normativas. São normas penais em branco, o que suscita a discussão acerca da sua legitimidade em um Estado Democrático de Direito.

\section{NORMA PENAL EM BRANCO E OPERABILIDADE: MODUS OPERANDI DA DOGMÁTICA PENAL BRASILEIRA}

Um dos princípios basilares do Direito Penal brasileiro, insculpido no art. $5^{\circ}$, inciso XXXIX, da Constituição Federal, preconiza que "não há crime sem lei anterior que o defina, nem

\footnotetext{
${ }^{2}$ Art. 56. Produzir, processar, embalar, importar, exportar, comercializar, fornecer, transportar, armazenar, guardar, ter em depósito ou usar produto ou substância tóxica, perigosa ou nociva à saúde humana ou ao meio ambiente, em desacordo com as exigências estabelecidas em leis ou nos seus regulamentos:

Pena - reclusão, de um a quatro anos, e multa.

$\S 1^{\circ}$ Nas mesmas penas incorre quem:

I - abandona os produtos ou substâncias referidos no caput ou os utiliza em desacordo com as normas ambientais ou de segurança;

II - manipula, acondiciona, armazena, coleta, transporta, reutiliza, recicla ou dá destinação final a resíduos perigosos de forma diversa da estabelecida em lei ou regulamento.

$\S 2^{\circ}$ Se o produto ou a substância for nuclear ou radioativa, a pena é aumentada de um sexto a um terço.

$\S 3^{\circ}$ Se o crime é culposo:

Pena - detenção, de seis meses a um ano, e multa. [...]

Art. 58. Nos crimes dolosos previstos nesta Seção, as penas serão aumentadas:

I - de um sexto a um terço, se resulta dano irreversível à flora ou ao meio ambiente em geral;

II - de um terço até a metade, se resulta lesão corporal de natureza grave em outrem;

III - até o dobro, se resultar a morte de outrem.

Parágrafo único. As penalidades previstas neste artigo somente serão aplicadas se do fato não resultar crime mais grave. [...]

Art. 60. Construir, reformar, ampliar, instalar ou fazer funcionar, em qualquer parte do território nacional, estabelecimentos, obras ou serviços potencialmente poluidores, sem licença ou autorização dos órgãos ambientais competentes, ou contrariando as normas legais e regulamentares pertinentes:

Pena - detenção, de um a seis meses, ou multa, ou ambas as penas cumulativamente.
} 
pena sem prévia cominação legal”. Trata-se do princípio da legalidade (nullum crimen, nulla poena sine praevia lege), cuja importância também se revela pela posição que ocupa no Código Penal brasileiro, que é inaugurado por dispositivo que contém justamente a mesma redação constitucional $\left(\operatorname{art.} 1^{\circ}\right)$.

Considerando que, como adverte Queiroz (2013, p. 76), os princípios penais representam limitações importantes ao poder de punir, razão pela qual são garantias (políticas) individuais oponíveis ao próprio exercício do poder punitivo estatal - ou seja, a Constituição pretende "proteger o indivíduo duplamente, isto é, por meio do Direito Penal e contra o Direito Penal” -, pode-se afirmar que, pelo princípio em questão, somente por lei, em sentido estrito (emanada do Legislativo), o Estado poderá definir as infrações penais e cominar sanções. Do contrário, é inconstitucional o ato normativo que o faça sem se revestir do caráter de lei.

No Brasil, é da União a competência constitucional privativa para legislar sobre Direito Penal. ${ }^{3}$ Os estados só podem fazê-lo em relação a questões específicas (e.g. o trânsito local) e desde que haja autorização por lei complementar para tanto. ${ }^{4}$

Para uma melhor compreensão do conteúdo do princípio da legalidade, pode-se desdobrálo em três subprincípios: a) taxatividade; b) irretroatividade da lei penal mais severa; c) reserva legal. Por taxatividade, entende-se que a lei deve descrever os tipos penais incriminadores com o máximo de precisão possível. O princípio implica a máxima determinação dos tipos penais, razão pela qual o Poder Legislativo, na elaboração da norma penal, deve formulá-la com a máxima precisão de seus elementos. Já a irretroatividade da lei penal mais severa significa que em nenhuma hipótese a lei penal poderá retroagir para prejudicar o réu. Logo: antes da lei, não há violação à lei. Caso contrário, a norma acabaria por incidir sobre condutas que até então não constituíam ilícito penal ou que eram punidas de modo mais brando. Assim, a norma penal somente pode ser aplicada a fatos futuros, salvo nas hipóteses em que servir para o favorecimento do réu, nos termos do que dispõe o art. $5^{\circ}, \mathrm{XL}, \mathrm{CF}$, estabelecendo sanção mais branda (lex mitior) ou descriminalizando a conduta (abolitio criminis) (QUEIROZ, 2013, p. 76). Por fim, a ideia de reserva legal encerra em si a exigência de que somente a lei pode dispor sobre matéria penal. Nesse sentido, convém salientar que o próprio conceito material de crime perde o sentido a partir da noção de reserva legal, uma vez que, para que uma ação seja considerada criminosa, não importa o desvalor social que é dado a ela.

\footnotetext{
${ }^{3}$ Art. 22. Compete privativamente à União legislar sobre:

I - direito civil, comercial, penal, processual, eleitoral, agrário, marítimo, aeronáutico, espacial e do trabalho;

${ }^{4}$ Art. 22, Parágrafo único. Lei complementar poderá autorizar os Estados a legislar sobre questões específicas das matérias relacionadas neste artigo.
} 
Tal desvalor somente servirá de parâmetro ao legislador, constituindo-se, assim, parte de uma etapa pré-legislativa, sendo incapaz de conceituar se a ação é ou não criminosa (CALLEGARI, 2014).

A submissão do Estado ao império da lei democraticamente produzida é um dos corolários do Estado Democrático de Direito, o que confere legitimidade ao Direito Penal. Tal ponderação decorre da compreensão de que as normas penais só encontram legitimação na medida em que geram mais liberdade do que a que sacrificam (CALLEGARI, 2007), razão pela qual, em um Estado Democrático de Direito, a seleção de respostas, instrumentos e estratégias para prevenção do fenômeno criminal, incluindo a intervenção do sistema punitivo, deve ser pautada em um cálculo de custos e benefícios sociais (BARATTA, 2000). Isto significa que em um Estado Democrático de Direito todas as limitações à liberdade individual devem ser legitimadas por seus benefícios sociais (ZÚÑIGA RODRÍGUEZ, 2001). O reconhecimento dos direitos fundamentais e a construção do Estado Democrático de Direito que o acompanha, como paradigmas do Direito (inclusive Penal) legítimo, são as mais importantes invenções ocidentais e a mais louvável conquista jurídica do ser humano, uma vez que “constituyen ideales con una legitimación axiológica capaz de oponerse a cualquier forma de opresión social e individual en el mundo” (ZÚÑIGA RODRÍGUEZ, 2001, p. 27).

Nesse diapasão, mesmo que a Constituição Federal não ofereça soluções categóricas sobre os limites ou objetivos da sanção punitiva estatal, cria um marco de valores para a decisão políticocriminal. Assim, o princípio da legalidade não transfere ao legislador ordinário uma ilimitada liberdade para fixar os conceitos de crime e de sanção penal (FELDENS, 2005).

Isso significa afirmar que “os Estados de Direito não são nada além da contenção dos Estados de polícia, penosamente conseguida como resultado da experiência acumulada ao longo das lutas contra o poder absoluto” (ZAFFARONI, 2007, p. 169). Quer dizer, o pacto social da Modernidade, o Direito moderno e suas Constituições, estão umbilicalmente ligados ao intento de conter a guerra, de civilizar e submeter a regras institucionais os conflitos políticos e sociais (BARATTA, 2000).

É justamente aqui que se coloca a questão das normas penais em branco, ou seja, daquelas normas incriminadoras que, embora cominem uma sanção penal, possuem um preceito que, por ser incompleto, depende de complementação por outra norma, geralmente de escalão inferior (decreto, regulamento, portaria, etc.). Na doutrina estrangeira recolhe-se lição segundo a qual a norma penal em branco é uma "lei marco", que se completa mediante outra norma posterior (SESSANO GOENAGA, 2002). Em texto clássico acerca do assunto na doutrina espanhola, García Arán (1993) 
salienta que as normas penais em branco se caracterizam pelo fato de que o estabelecimento do pressuposto remete a outra instância não legislativa que, em definitivo, exerce a ameaça penal.

A doutrina brasileira classifica as normas penais em branco em dois grandes blocos. A partir da obra de Edmund Mezger, Alflen da Silva (2004) assevera que é possível distinguir normas penais em sentido "amplo” e em sentido "estrito”. No primeiro caso (leis penais em branco em sentido amplo), o tipo penal e a sanção cominada apresentam-se externamente separados, uma vez que a sanção vincula-se apenas a um tipo que necessita ser complementado, o que pode ocorrer de duas maneiras: ou a complementação necessária encontra-se na mesma lei, revelando um problema de "técnica legislativa”, ou a complementação deve ser buscada em uma lei diversa da mesma instância legislativa. No segundo caso, no entanto (leis penais em branco em sentido estrito), a complementação necessária à norma advém de uma lei que pertence a uma outra instância legislativa, o que impõe uma maior preocupação com o princípio da legalidade. Afinal, como destacam Zaffaroni e Pierangeli (1999, p. 450), “o Poder que complementa a lei em branco deve ter o cuidado de respeitar a natureza das coisas porque, do contrário, através de tal recurso pode ser mascarada uma delegação de competências legislativas penais.”

Em síntese, Alflen (2007, p. 7) conceitua leis penais em branco como aquelas que "fixam a cominação penal, mas descrevem o conteúdo da matéria de proibição de modo genérico (o branco), remetendo expressa ou tacitamente à [sic] outros dispositivos de lei (remissão interna ou externa) ou emanados de órgãos de categoria inferior, para precisá-lo”.

Nesse sentido, pode-se afirmar que a Lei dos Crimes Ambientais - nos casos específicos dos dispositivos investigados neste texto (art. 56 e seguintes) - alberga normas penais em branco que podem ser consideradas em sentido amplo e em sentido estrito, dado que a sua complementação depende, em alguns casos, de uma norma oriunda de uma fonte normativa heterônoma. Nesse ponto, suscita-se o debate acerca do fato de que, nos casos de normas penais em branco em sentido estrito, o conteúdo da norma penal poderá ser modificado independentemente da existência de uma discussão amadurecida da sociedade a respeito da alteração.

Com efeito, no processo legislativo formal da União, os projetos de lei são submetidos à apreciação de ambas as casas do Congresso Nacional, sendo levada em consideração a vontade do povo, representado pelos seus deputados, bem como a dos estados, representados pelos seus senadores, além do necessário controle exercido pelo Poder Executivo, que exercita o sistema de freios e contrapesos (GRECO, 2003). Nesse sentido, permitir-se, por exemplo, que uma portaria ou resolução oriunda de órgão ou ente da Administração Pública Federal (direta ou indireta) - ou seja, integrante do Poder Executivo - sirva para complementar o sentido de uma norma penal em branco 
significaria o mesmo que compreendê-la como "uma espécie de cheque em branco emitido em favor do Executivo” (QUEIROZ, 2013, p. 84). Isso representaria, ao mesmo tempo, uma violação ao

[...] princípio da reserva legal, por tolerar que simples portaria emanada do Poder Executivo possa dispor sobre matéria penal, criminalizando uma dada conduta, e o princípio da divisão dos poderes, já que é aquele poder, e não o Legislativo, que acaba legislando em tal caso (QUEIROZ, 2013, p. 84).

Isso fica muito evidente no caso dos artigos 56 e seguintes da Lei de Crimes Ambientais, uma vez que o tipo penal não apresenta, no seu preceito primário, qual/quais produto(s) ou substância(s) que se considera(m) tóxico(s), perigoso(s) ou nocivo(s) à saúde humana ou ao meio ambiente. Ou seja, para aplicação das normas em questão, é imprescindível que o intérprete recorra a outra(s) norma(s), para saber o seu alcance. Desse modo, é apenas a partir da análise do ato normativo expedido pelo órgão ambiental competente que o intérprete poderá inferir se uma dada substância é considerada tóxica, perigosa ou nociva à saúde humana ou ao meio ambiente. Em outras palavras: a configuração do objeto material do crime em comento não se esgota na análise do preceito mencionado, uma vez que a indicação das substâncias tóxicas, perigosas e nocivas à saúde humana ou ao meio ambiente dependem de uma deliberação da autoridade ambiental.

O problema reside no fato de que o estabelecimento desse rol de substâncias/produtos fica a exclusivo critério da autoridade administrativa, que não se submete a um processo legislativo democrático (discussão amadurecida da norma pela sociedade) para que possa criar/alterar essa relação, seja para nela incluir novas substâncias/produtos - criando novas hipóteses de criminalização de condutas -, seja para suprimir as substâncias/produtos já existentes - criando hipóteses de descriminalização. Com isso, fere-se o disposto no art. 22, inciso I, do texto constitucional e, reflexamente, uma das garantias máximas do cidadão na seara das práticas punitivas: a legitimidade democrática que advém de um processo legislativo formal. Afinal de contas, quem acaba por definir o que configura crime nessas hipóteses mencionadas é um órgão ligado ao Poder Executivo, o que representa uma flagrante violação ao princípio da legalidade, na medida em que essa atribuição, em um ambiente de Estado Democrático de Direito, é exclusiva do Poder Legislativo, na qualidade de representante do povo.

Por outro lado, alguns autores entendem que a técnica empregada pelo legislador no art. 56 da Lei de Crimes Ambientais decorre da complexidade que a tutela penal do meio ambiente impõe (FREITAS, 2006). Na ótica de Luis Rodríguez Ramos (1986, p. 39), há condutas que não se podem 
descrever sem acudir a esta técnica, como, por exemplo, no caso do conceito conexo de “contaminação”, que só pode ser determinado mediante uma remissão a outras normas.

No Brasil, autores como Luiz Regis Prado (2009, p. 84) entendem que não se cogita a inconstitucionalidade das normas penais em branco em matéria ambiental, a não ser nos casos em que não haja clareza e determinação da parte dispositiva da norma. Logo, se a lei penal se "revestir das notas de clareza e exaustividade na descrição do pressuposto" e for "precisa ao assinalar a consequência”, não há ofensa à legalidade insculpida no art. 5 XXXIX, CF.

Ocorre que, como salienta José Afonso da Silva (2002), uma das questões mais delicadas da Política Nacional do Meio Ambiente reside exatamente na qualidade dos meios normativos de sua execução. Segundo o autor, há no Brasil, desde o período ditatorial, um habitus de atuar, em relação a essa matéria, por meio de portarias e resoluções de órgãos do Sistema Nacional do Meio Ambiente, o que facilita a sua criação e alteração. No entanto, se essa flexibilidade por um lado é conveniente - particularmente diante de situações de emergência -, "por outro importa insegurança jurídica para os destinatários desses instrumentos infralegais”, de modo que se deve aferir, “em cada caso, até que ponto a situação regulada não exigiria lei, a fim de resguardar o princípio da legalidade, que se acha inscrito no art. 5º II da Constituição da República” (SILVA, 2002, p. 211).

Nesse ponto, não se pode descuidar de outro aspecto relacionado à tutela penal do meio ambiente: a utilização de normas penais em branco na Lei de Crimes Ambientais pode ser compreendida como uma consequência do processo de expansão do Direito Penal na realidade brasileira (WERMUTH, 2011). O Direito Penal passa a ser instrumentalizado no sentido de evitar que os riscos se convertam em situações concretas de perigo e, no lugar de um direito punitivo que reagia a posteriori contra um feito lesivo individualmente delimitado, surge um modelo de gestão punitiva dos riscos em geral, tornando-se possível falar em um processo de administrativização do Direito Penal. Em seu bojo, esse fenômeno traz uma supervalorização e o consequente incremento punitivo de infrações de deveres de cuidado, de forma a dar resposta não só aos delitos de perigo abstrato, mas também aos chamados delitos de acumulação, ${ }^{5}$ no marco da luta contra as novas formas de criminalidade (SILVA SÁNCHEZ, 1999).

\footnotetext{
${ }^{5}$ Os delitos de acumulação são aqueles que, enquanto condutas individuais, não causam, por si sós, lesão ou perigo a bens jurídicos, mas que, considerados em conjunto - ou seja, se praticados por outros sujeitos -, conduzem a uma situação de lesão ao bem jurídico tutelado. Trata-se, aqui, “de casos en que la conducta individualmente considerada no muestra un riesgo relevante (es 'harmless'), mientras que, por outro lado, se admite que 'general performance would be harmful' y que dicha realización por una pluralidad de personas no constituye simplemente una hipótesis, sino que es una realidad actual o inminente” (SILVA SÁNCHEZ, Jesús-Maria. La expansión del Derecho penal: aspectos de la política criminal en las sociedades postindustriales. Madrid: Cuadernos Civitas, 1999, p. 108-109).
} 
Pérez Cepeda (2007, p. 321) salienta, a propósito, que se vive na contemporaneidade, na seara do discurso jurídico-penal, uma autêntica “cultura preventiva”, na qual "la preocupación social no es tanto cómo obtener lo que se desea, sino cómo prevenir de daños lo que se tiene”, o que gera uma intervenção penal desproporcionada

[...] en la que resulta prioridad únicamente la obtención del fin perseguido, la evitación del riesgo en el 'ámbito previo' a la lesión o puesta en peligro, adelantando la intervención penal, o general, suprimiendo garantías en busca de la presunta eficacia (PÉREZ CEPEDA, 2007, p. 321).

Configura-se, assim, uma legislação penal no pretérito imperfeito do subjuntivo, a partir da qual "los comportamientos que se van a tipificar no se consideran previamente como socialmente inadecuados, al contrario, se criminalizan para que sean considerados como socialmente desvalorados” (PÉREZ CEPEDA, 2007, p. 313). E para adiantar a intervenção punitiva são utilizadas estruturas típicas de mera atividade, ligadas aos delitos de perigo abstrato, em detrimento de estruturas que exigem um resultado material lesivo (perigo concreto). Nesse sentido, Alflen (2007) observa que o Direito Penal passa ser visto exclusivamente como um instrumento de solução dos conflitos sociais, não mais sendo possível distingui-lo "tanto quanto à sua utilidade, como pela sua gravidade, dos outros instrumentos de solução destes conflitos, de maneira que, apesar dos seus instrumentos rigorosos, o Direito Penal torna-se um soft law, um meio de manobra social”.

Paralelamente à antecipação da intervenção punitiva, verifica-se um desapreço cada vez maior pelas formalidades e garantias penais e processuais penais características do Direito Penal liberal, que passam a ser consideradas como “obstáculos” à eficiência que se espera do sistema punitivo diante da insegurança da contemporaneidade. A partir do fenômeno expansivo vivenciado pelo Direito Penal, além do incremento dos comportamentos elevados à categoria delitiva por meio da antecipação da intervenção punitiva ao estágio prévio à efetiva lesão dos bens jurídicos, verificase um processo de flexibilização das garantias político-criminais materiais e processuais, mediante o desrespeito ao princípio da legalidade penal, a redução das formalidades processuais, a violação ao princípio da taxatividade na elaboração dos tipos penais, a violação ao princípio da culpabilidade, etc. Atenta a esta realidade, Pérez Cepeda (2007, p. 330-331) assevera que

[...] aparecen significativas modificaciones en el sistema de imputación de responsabilidad y en el conjunto de garantías penales e procesales, en la medida en que se admiten ciertas perdidas en el principio de seguridad jurídica derivadas de la menor precisión en la descripción de los comportamientos típicos y del uso frecuente de la técnica de las leyes penales en blanco, que confia la delimitación del ámbito de lo prohibido a la normativa administrativa, con el consiguiente vaciamiento de la antijuridicidad, que pasa a ser puramente formal; se hace una interpretación generosa de la lesividad real o potencial de 
ciertos comportamientos, como en la punición de determinadas tenencias o en el castigo de desobediencias.

Estas características que o Direito Penal - orientado ao enfrentamento aos novos riscos, medos e inseguranças da contemporaneidade - apresenta acenam para o fato de que se está diante da configuração de um modelo de intervenção punitiva que representa um sério risco às liberdades e garantias fundamentais do cidadão. Com efeito, "ao retirar as garantias do Direito Penal em geral [...] será eliminada a sua potência jurídica protetora e se terão instrumentos que não servirão para nada ou tão só ao arbítrio punitivo” (ALFLEN, 2007, p. 17).

No entanto, uma questão que se coloca, no caso específico das nanotecnologias e da responsabilidade penal delas decorrente, diz respeito a uma crítica que se estabelece ao constitucionalismo calcado na ideia de Estado-nação, bem como sobre a própria efetividade do Direito Penal em cumprir com sua função de tutela ambiental, assunto com o qual se ocupa o tópico que segue.

\section{PLURALISMO JURÍDICO E NORMATIVIDADE: (PÓS-)MODERNIDADE E DESAFIOS À GARANTIA DA LEGALIDADE}

É notável o fato de que a contemporaneidade assiste ao processo de emergência de um Direito mundial para além das ordens políticas do tipo nacional e internacional, no qual "setores sociais produzem normas com autonomia relativa diante do Estado-nação, formando um ordenamento jurídico sui generis” (TEUBNER, 2003, p. 9). A institucionalização típica do Estadonação não será, num futuro breve, capaz de dominar as forças centrífugas da sociedade civil mundial.

Apresentam-se várias formas de ordenamento jurídico transnacional, desvinculadas do Estado-nação e da política internacional: a lex mercatoria (ordenamento jurídico dos mercados mundiais); os ordenamentos jurídicos dos grupos empresariais multinacionais; a normatização do mercado laboral relacionada às empresas e sindicatos (atores privados); as normas supranacionais de padronização técnica e de autocontrole profissional; a ordem dos Direitos Humanos (que é, concomitantemente, estatal e contraestatal); alguns mecanismos jurídicos que buscam a proteção ambiental; a regulação dos esportes em nível global.

Uma teoria jurídica pluralística readequada às novas fontes do direito, que considere os processos espontâneos da formação de direito na sociedade mundial independentes das esferas estatais e interestatais, deve ser concebida (TEUBNER, 2003, p. 32). Apenas uma teoria deste tipo, que trate de um Direito oriundo de discursos (e não apenas relacionado a grupos) permitiria uma 
interpretação adequada do Direito global. Ao lado dela, deve se fazer presente uma nova teoria das fontes do Direito, reconcebida de forma pluralista - em que as fontes seriam oriundas de processos independentes das instituições estatais (individualmente ou de maneira internacional).

Não é possível, portanto, analisar os âmbitos do Direito global como sendo ele oriundo (ou necessariamente identificado) de (ou com) processos político-jurídicos de cunho estatal: é um “discurso jurídico autorreprodutor de dimensões globais que cerra as suas fronteiras mediante recurso ao código binário 'direito/não-direito' [...] e reproduz a si mesmo mediante o processamento de um símbolo de vigência global” (TEUBNER, 2003, p. 18. Grifo do autor). Com isto, categorias importantes para a observação tradicional do Direito - tais como norma, controle social e, especialmente, sanção - ficam relegadas a segundo plano, sendo seus lugares assumidos por outras como gramática, enunciação, ato de fala, paradoxo e transformação de diferenças (que prometem uma capacidade de compreensão mais aprofundada do pluralismo jurídico emergente).

Apesar de estar distanciado da política nacional e do Direito Internacional, o novo Direito global não é apolítico, pois o modus operandi dos novos atores jurídicos globais o repolitiza porém, por meio de processos pelos quais o Direito é acoplado a discursos sociais altamente especializados e politizados, não de políticas institucionais tradicionais (TEUBNER, 2003, p. 10).

No bojo do sistema social da sociedade mundial encontram-se vários subsistemas e organizações dotados de sentido comunicativo - os quais interagem com os demais de forma irritativa (ou pressionante). Tais organizações e subsistemas estão para além daquilo que concirna ao Estado nacional e seus elementos: também está para além das organizações internacionais (fundadas, portanto, a partir da noção estatal). Está, ainda, para além de qualquer ordem política, jurídica e normativa relacionada a este tipo de ente.

A busca por soluções normativas de questões complexas diversas das tradicionais teorias de cunho legalista e normativista tem levado autores a formular propostas relacionadas a um diálogo entre ordens normativas dos mais diversos âmbitos e níveis. Estas novas propostas teóricas levam em consideração as já tradicionais fontes relacionadas às ordens estatais (oriundas de um processo legislativo estatal ou formas derivativas), normas de cunho internacional (sendo destacada a normatização fundada nos Direitos Humanos), bem como as respostas jurídicas relacionadas a setores não estatais da sociedade civil. Dentre tais propostas, destaca-se a de Wilson Engelmann (2012), que propõe uma teoria dialogal de fontes estatais e não-estatais - e, para efeitos do presente trabalho, merecem especial destaque as normas oriundas dos processos globais de padronização, tais como a International Organization for Standardization (ISO), rede de corpos nacionais de padronização técnica (164 no total) (INTERNATIONAL ORGANIZATION FOR 
STANDARDIZATION, 2013), sendo que cada membro (que, em alguns casos, são partes da estrutura governamental dos seus Estados; em outros, são organizações do setor privado) se traduz no mais representativo do seu país e, ao mesmo tempo, assume o papel de ponto focal para as atividades da ISO.

Para a consecução dos seus objetivos, esta organização se vale do debate fundamentado no conhecimento técnico-científico e de mercado, a fim de facilitar o processo de produção industrial (o que traz implicações econômicas interessantes), bem como o estabelecimento de parâmetros deônticos de valor jurídico.

Fundada em 1947, publicou desde então mais de 19.000 normas de caráter internacional que abarcam quase todos os aspectos da tecnologia e dos negócios: da segurança alimentar à tecnologia de informação, da agricultura à saúde (INTERNATIONAL ORGANIZATION FOR STANDARDIZATION, 2010, p. 2-3). Assim, pode-se identificar, na produção de suas comunicações normativas, uma possibilidade de impacto em vários setores da vida humana e do meio ambiente - principalmente nas cerca de 30 (trinta) normas já aprovadas pelo TC 229 da ISO, responsável pelo tema das nanotecnologias (INTERNATIONAL ORGANIZATION FOR STANDARDIZATION, 2005).

Argumenta-se no sentido de defender a regulação do risco nanotecnológico de modo a fazer com que normas estatais e internacionais dialoguem com normatizações provenientes de organizações tais como a ISO por diversas razões. Em primeiro lugar, observem-se os erros cometidos nos Projetos de Lei submetidos à análise e voto no Legislativo brasileiro acerca da regulamentação das nanotecnologias. É notável que, ao lado de uma repetição legislativa retrógrada e injustificável (pois se repetia, de modo fastidioso, aquilo que já se encontrava no cerne de outras leis vigorantes), tais normas realizavam generalizações semânticas que poderiam redundar, futuramente, em impasses interpretativos (simplesmente denominar "nanotecnologia” uma ampla gama de possibilidades futuras, por exemplo).

Este diálogo, porém, não pode vir a significar a mera aplicação do “padrão ISO” como preenchimento da norma penal em branco. Está-se, isso sim, a querer demonstrar que há desafios perturbadores da sintaxe da dogmática moderna do Direito - principalmente no que tange ao princípio da legalidade na definição de penas. Ora, até mesmo um ente não-estatal tem se demonstrado mais eficaz do que o Estado (figura chave da Modernidade). Este, detentor único do direito à persecução penal, tem se demonstrado incapaz, em razão de suas processualísticas internas, de regular as questões mais sensíveis e amplas do Direito Penal Ambiental, quais sejam, as atividades poluidoras por grandes empresas. 
O eventual diálogo que se propõe entre a ordem estatal e a ordem não-estatal de padronização técnica perpassaria, assim, apenas pelo nível (não hierárquico) analítico-temático. Isto significa que o Estado, em processos legislativos (estritamente considerados), deveria analisar dialogalmente estes padrões, verificar se estão acordes aos seus postulados fundamentais, e apenas após este exercício sancionar leis (estritamente consideradas) estabelecedoras de padrões para o preenchimento da norma penal em branco.

Veja-se, contudo, que nas normas da ISO não se esgotam as possibilidades dialogais para com outras ordens normativas provenientes de organizações da sociedade civil global - trata-se, apenas, de uma possibilidade bastante sólida, já que vários pontos nodais entre a ordem jurídica estatal brasileira e a ordem então em comento já estão estabelecidos. Ademais, apenas questões mais específicas (acerca das dimensões de nanopartículas, de normas para a saúde humana quando em contato com tais materiais, etc.) seriam daí provenientes: outras ordens (nacionais, internacionais, de direitos humanos, etc.) teriam participação em tal procedimento compreensivo.

Não é uma absolutização do papel da ISO na gestão dos riscos da nanotecnologia o que se propõe: a referida ordem normativa seria um elemento importante dentro da hipótese de diálogo que se está propondo com este trabalho. Trata-se, assim, do oferecimento de maior atenção à comunicação daí proveniente no sistema do Direito. Legar à matéria grande dependência de legislação específica é relegá-la às contingências de um tempo de processamento legislativo longo demais - processo este que não necessariamente trará uma regulação efetivamente producente, já que o Direito apenas observa a legislação (e, a partir dela e de outros elementos, decide com base em seu programa e código).

A policontexturalidade e a hipercomplexidade atuais desafiam a dogmática penal tradicional até mesmo no nível das garantias ao acusado. A complexidade tecnológica, econômica, política, jurídica - enfim, social - faz com que o tempo legislativo se demonstre longo demais para as exigências normativas da Pós-Modernidade (já que o tempo entre a proposição legislativa e sua eventual entrada em vigor superam em muito aquele das mudanças de geração tecnológica, muitas vezes relegando normas à carência de sentido antes que sua validade se inicie). Por outro lado, não se pode abandonar as garantias fundamentais - tais como a da legalidade - em nome do eficientismo da persecução penal. Isso significa apenas substituir um risco pelo outro, como já assinalado nas considerações introdutórias deste artigo: no caso das nanotecnologias, especificamente, significa proteger o meio ambiente do risco nanotecnológico à custa da criação de um risco político-criminal representado pela mitigação/eliminação de garantias historicamente conquistadas. 
E, nesse contexto, pode-se afirmar ainda mais: que sentido faz a persecução penal tradicional - que trancafia o indivíduo - diante do cenário da degradação ambiental por nanotecnologias? As exigências técnicas mais básicas para a concretização da pesquisa e da produção envolvendo nanotecnologia demonstram que, na maioria dos casos, seriam provavelmente grandes companhias os maiores poluidores. Neste cenário, para uma efetividade da aplicação da pena não apenas no sentido de educação, mas também de retribuição, punir qualquer pessoa natural seria apenas fomentar o sentimento de vingança social contra um indivíduo, sem que os verdadeiros responsáveis, detentores do poderio econômico pulverizado na lógica dos interesses dos acionistas, fossem atingidos.

Em última análise, pode-se afirmar que o Direito Penal, diante de muitas situações da complexa tessitura societal da contemporaneidade - como é o caso da tutela ambiental em face do risco nanotecnológico - só apresenta (e só pode apresentar) respostas simbólicas (DÍEZ RIPOLLÉS, 2002), o que remete à célebre parábola do açougueiro criada pelo penalista argentino Eugenio Raúl Zaffaroni: ${ }^{6}$ assim como o açougueiro só entende de seu pequeno comércio de carnes, o Direito Penal somente entende de imposição de penas. Dessa forma, assim como o açougueiro não pode pretender dar palpites sobre, por exemplo, roteiros de viagens, o Direito Penal também não pode, por si só, resolver a questão da criminalidade. Caso o pretenda, ele se transforma em um embuste, em uma fraude: ele se diz útil para o que não é, e seu discurso se desarma ao mais leve toque com a realidade (ZAFFARONI, 2001).

Os instrumentos necessários para uma eventual consecução da poluição ambiental por nanopartículas são tão desenvolvidos (e caros) que se torna impossível para qualquer indivíduo a sua aquisição. Ao desenvolvimento das pesquisas, além das facilidades normais de um laboratório de pesquisa de materiais, é imprescindível a "sala limpa”, 7 novas gerações de microscópios de alta resolução (transmissão, varredura, força-atômica, tunelamento) e as espectroscopias/microscopias ópticas confocais, que utilizam métodos fluorescentes e de ótica não-linear (ALVES, 2004, p. 31). Já a produção industrial demanda, principal mas não unicamente, além de todas as facilidades laboratoriais recém exemplificadas, máquinas e instrumentos para a fabricação, montagem, testes e

\footnotetext{
${ }^{6}$ A parábola em questão foi contada por Zaffaroni em conferência realizada no Brasil, no Guarujá, em 16 de setembro de 2001.

${ }^{7}$ Conforme explica J. Fernando B. Britto, segundo a definição dada na NBR 13413, sala limpa "é o ambiente no qual o suprimento e a distribuição do ar, sua filtragem, os materiais de construção e procedimentos de operação visam controlar as concentrações de partículas em suspensão no ar, atendendo aos níveis apropriados de limpeza conforme definido pelo usuário e de acordo com normas técnicas vigentes”. (BRITTO, J. Fernando B. Projeto básico de salas limpas. Revista da SBCC, São José dos Campos, n. 54, p. 46-61, setembro/outubro 2011, p. 46).
} 
controle de qualidade (ALVES, 2004, p. 31). E não se pode esquecer também, por óbvio, o uso dos mais potentes computadores e processadores possíveis.

Nota-se que, dogmaticamente, a dosimetria da pena no caso de o condenado ter incorrido no tipo penal do artigo 56 da Lei no 9.605/98 deve ser a reclusão entre 01 (um) e 04 (quatro) anos. Penas restritivas de liberdade inferiores a 04 (quatro) anos, de acordo com o artigo $7^{\circ}$, incisos I e II, da mesma Lei, ${ }^{8}$ podem ser substituídas por penas restritivas de direitos. No rol de penas restritivas de direitos do artigo $8^{\circ}$ da mesma Lei encontram-se opções retributivas muito mais eficientes, em relação a empresas que eventualmente possam vir a ser condenadas por danos ambientais decorrentes da poluição por nanopartículas, do que a reclusão (prestação de serviços à comunidade, interdição temporária de direitos, suspensão parcial ou total de atividades, prestação pecuniária e recolhimento domiciliar). ${ }^{9}$

Há também de se constatar que a inovação legislativa penal da Lei de Crimes Ambientais ora em vigor permite a responsabilização penal da pessoa jurídica. ${ }^{10} \mathrm{Em}$ casos nos quais se verifica ter a ordem de liberar nanopartículas indiscriminadamente no meio ambiente partido da direção da empresa, há muito mais sentido em punir a empresa com alguma pena retributiva realmente útil para o entorno - como a prestação de serviços à comunidade e a prestação pecuniária, as quais seriam conversíveis em atividades que fazem mais sentido do que a mera reclusão de pessoas físicas envolvidas no fato (sem consideração à importância da pessoa jurídica).

Neste estado de coisas, todavia, ainda persiste a questão: é juridicamente possível sustentar a posição de que órgãos (ou entes) exteriores ao Poder Legislativo estatal estabeleçam róis que preencham normas penais em branco? A atual complexidade pode até servir de argumento que proporcione uma resposta afirmativa à questão; porém, esta posição jurídica sintática desafia a

\footnotetext{
${ }^{8}$ Art. $7^{\circ}$ As penas restritivas de direitos são autônomas e substituem as privativas de liberdade quando:

I - tratar-se de crime culposo ou for aplicada a pena privativa de liberdade inferior a quatro anos;

II - a culpabilidade, os antecedentes, a conduta social e a personalidade do condenado, bem como os motivos e as circunstâncias do crime indicarem que a substituição seja suficiente para efeitos de reprovação e prevenção do crime.

Parágrafo único. As penas restritivas de direitos a que se refere este artigo terão a mesma duração da pena privativa de liberdade substituída.

${ }^{9}$ Art. $8^{\circ}$ As penas restritivas de direito são:

I - prestação de serviços à comunidade;

II - interdição temporária de direitos;

III - suspensão parcial ou total de atividades;

IV - prestação pecuniária;

V - recolhimento domiciliar.

${ }^{10}$ Art. $3^{\circ}$ As pessoas jurídicas serão responsabilizadas administrativa, civil e penalmente conforme o disposto nesta Lei, nos casos em que a infração seja cometida por decisão de seu representante legal ou contratual, ou de seu órgão colegiado, no interesse ou benefício da sua entidade.
} 
semântica dos Direitos Fundamentais - mormente no que tange à garantia fundamental da legalidade.

Ademais, não se pode deixar de levantar a questão de que a própria garantia da legalidade pode servir de argumento para que seja obliterada a consecução do caráter retributivo da pena no que tange à poluição. Atravanca-se o processo legislativo de modo a não regulamentar questões atinentes à matéria (em prol dos interesses econômicos); atravanca-se também o Judiciário com questões oriundas da constitucionalidade das estratégias de preenchimento da norma penal em branco. Durante tais impasses, permanece desregulada a questão da poluição por nanopartículas, e a própria ausência legislativa se converte em conundrum possibilitador da continuidade da exploração indiscriminada desta tecnologia - e esvazia-se a persecução criminal de sentidos e possibilidades.

\section{CONSIDERAÇÕES FINAIS}

É urgente a regulação das atividades que proporcionam o risco nanotecnológico à sociedade e ao meio ambiente - seja na esfera penal, seja na cível, seja ainda na administrativa. Há diversos danos que tais atividades podem proporcionar à saúde humana, ao meio ambiente ecologicamente equilibrado e, portanto, à sociedade como um todo. Apesar da relutância do Poder Legislativo em aprovar alguma lei que verse sobre o risco nanotecnológico, já se fazem presentes diversos instrumentos legislativos capazes de servir de fundamento à disciplina estatal da matéria dentre eles, a Lei ${ }^{\circ}$ 9.605/1998.

Porém, nota-se que o principal (mas não único) dispositivo do referido diploma é caracterizável como norma penal em branco, eis que exige sua regulamentação por outra(s) lei(s) ou regulamento(s). Frente a esse vácuo de padrões normativos pela lei, nota-se que a dogmática jurídica tem reconhecido a legitimidade de portarias e regulamentos (tais como a Portaria $\mathrm{n}^{\circ}$ 344/1998 da Anvisa, para estabelecer quais drogas são consideradas proscritas no Brasil), a fim de estabelecer padrões de proibição para diversas questões.

Esta via de regulamentação - mediante o estabelecimento de listas por órgãos do Poder Executivo (Administração Direta ou Indireta) parece, sintaticamente, ferir o princípio da legalidade constitucionalmente estabelecido. Isto porque, se entendido o ato privativo da União de legislar sobre Direito Penal como sendo ato de legalidade estrita, atos normativos infralegais (tais como portarias e resoluções, mesmo que sejam de entes ou órgãos vinculados à União) não caberiam dentro da categoria Lei (mesmo que uma lei - ordinária ou complementar - venha a legitimar sua adoção para o estabelecimento de padrões). 
Parece configurar tendência autoritária, na repressão criminal, legar a órgãos e entes vinculados ao Poder Executivo boa parte do poder legiferante - o qual, até mesmo etimologicamente, pertenceria ao Poder Legislativo. Incumbir atividade juridicamente tão importante ao Executivo ameaça a ordem de direitos e garantias fundamentais sintática e semanticamente estabelecidos pelo constitucionalismo moderno, eis que não teriam sido os representantes do povo participantes no processo de escolha dos profissionais que estabelecem tais listas. Delegar a outrem a tarefa constitucionalmente legislativa é solução concorde ao eficientismo mecânico que atropela a ordem de direitos fundamentais no seu ponto, talvez, mais sensível - qual seja, a legalidade.

Por outro lado, não se pode deixar de contrapor a este importante argumento a questão da complexidade atual. Aguardar o processo legislativo para o estabelecimento de padrões em qualquer situação que exija a expertise de outras áreas (ciência, tecnologia, etc.) demonstra-se enfadonho e anacrônico, dadas sua demora e falta de especialização - com exceção, talvez, da possibilidade de discussão em consultas populares e câmaras temáticas do Legislativo (as quais acresceriam ainda mais tempo ao processo). Assim, a delegação a outros órgãos e entes seria a solução logicamente mais eficiente (no pensamento atual).

Aliás, na atual situação social policontextural e hipercomplexa, até mesmo entes nãoestatais capazes de produzir sentido jurídico se revelam mais rápidos - e, quiçá, mais competentes (no que tange à ciência e à tecnologia) do que o próprio Estado. Enquanto a tecnologia se desenvolve (e supera suas próprias gerações no tempo), a própria sociedade civil global se organiza em torno de outros centros de produção normativa, muitas vezes mais atualizados do que aquilo que o próprio Estado produz no que toca a este tipo de matéria.

Tratar da persecução penal com caráter meramente repressivo parece não ser a tônica mais adequada à discussão acerca da norma penal em branco e seu preenchimento. Há de se reconhecer uma necessidade de diálogo na produção normativa para com outros entes (que já estão mais avançados na padronização técnica) em vez da mera relegação ao Executivo. Contudo, não se pode fornecer uma abertura exagerada, eis que isto seria a própria morte da persecução penal como prerrogativa pública.

Há de se argumentar que, pragmaticamente, a persecução criminal de atos tão complexos quanto a poluição por nanopartículas é, mais adequadamente, atribuível a pessoas jurídicas de grande porte, com grandes interesses econômicos - as quais, em vez de serem punidas de modo tradicional, mais propiciamente deveriam retribuir à sociedade e ao ambiente. Dessa forma, a questão da responsabilidade penal ambiental em virtude de poluição por nanopartículas acaba por 
evidenciar o próprio papel desempenhado pelo Direito Penal em um Estado Democrático de Direito: trata-se, em última análise, de um papel estritamente simbólico? A questão suscitada no presente texto serve, portanto, para que se possa refletir acerca da aptidão e da legitimidade de se utilizar o direito penal de forma ampla. Os percalços apontados ao longo do texto evidenciam que medidas administrativas, punições em âmbito cível e penas alternativas - devidamente reformuladas - podem ser bem mais adequadas e legítimas para o enfrentamento de questões tão complexas como o risco nanotecnológico do que a persecução penal tradicional, embasada na reclusão.

\section{REFERÊNCIAS}

ALFLEN DA SILVA, Pablo Rodrigo. Leis penais em branco e o direito penal do risco: aspectos críticos e fundamentais. Rio de Janeiro: Lumen Juris, 2004.

ALFLEN, Pablo. O risco da técnica de remissão das leis penais em branco no Direito Penal da Sociedade do Risco. Política Criminal. $\mathrm{n}^{\mathrm{o}}$ 3, 2007. A7, p. 1-21. Disponível em: <http://www.politicacriminal.cl/n_03/a_7_3.pdf>. Acesso em: 05 maio 2015.

ALVES, Oswaldo. Nanotecnologia, nanociência e nanomateriais: quando a distância entre presente e futuro não é apenas questão de tempo. Revista Parcerias Estratégicas, Brasília, n. 18, p. 23-40, 2004.

BARATTA, Alessandro. La política criminal y el derecho penal de la constitución: nuevas reflexiones sobre el modelo integrado de las ciencias penales. Revista Brasileira de Ciências Criminais, n. 29. São Paulo: Revista dos Tribunais, 2000.

BRASIL. Agência Nacional da Vigilância Sanitária. Portaria $n^{\circ}$ 1.358, de 20 de agosto de 2014. Institui o Comitê Interno de Nanotecnologia da Agência Nacional de Vigilância Sanitária - Anvisa e dá outras providências. Disponível em: <http://goo.gl/OKYWC1>. Acesso em: 10 mar. 2015.

. Decreto n. 6.112, de 12 de maio de 2007. Promulga o Acordo de Cooperação Científica e Tecnológica entre o Governo da República Federativa do Brasil e a Comunidade Europeia, celebrado em Brasília, em 19 de janeiro de 2004. Disponível em: <http://goo.gl/xMBiPE>. Acesso em: 30 set. 2014.

. Diário da Câmara dos Deputados, Ano LXII, n. 203, 20 de dezembro de 2008. Disponível em: <http://goo.gl/cjYU77>. Acesso em: 26 mar. 2013.

. Diário do Senado Federal, $\mathrm{n}^{\circ}$ 115, 02 de agosto de 2013. Disponível em: <http://goo.gl/vu787Z>. Acesso em: 03 out. 2013.

. Lei $n^{\circ}$ 9.605, de 12 de fevereiro de 1998. Dispõe sobre as sanções penais e administrativas derivadas de condutas e atividades lesivas ao meio ambiente, e dá outras providências. Disponível em: <http://www.planalto.gov.br/ccivil_03/leis/19605.htm>. Acesso em: 23 mar 2015. 
. Ministério da Ciência, Tecnologia e Inovação. Gabinete do Ministro. Instrução Normativa $n^{\circ}$ 2, de 15 de junho de 2012. Diário Oficial [da] República Federativa do Brasil, Poder Executivo, Brasília, DF, ano 149, nº 123, seção 1, p. 4, 27 jun. 2012b.

. Ministério da Ciência, Tecnologia e Inovação. Gabinete do Ministro. Portaria $n^{\circ}$ 245, de 5 de abril de 2012. Diário Oficial [da] República Federativa do Brasil, Poder Executivo, Brasília, DF, ano 149, n ${ }^{\circ}$ 68, seção 1, p. 5, 09 abr. 2012a.

BRITTO, J. Fernando B. Projeto básico de salas limpas. Revista da SBCC, São José dos Campos, n. 54, p. 46-61, setembro/outubro 2011.

CALLEGARI, André Luís. Direito Penal e Constituição: condições e possibilidades de uma adequada aplicação da pena. In: SANTOS, A. L. C.; STRECK, L. L.; ROCHA, L. S. (Org.). Constituição, sistemas sociais e hermenêutica. Porto Alegre: Livraria do Advogado; São Leopoldo: UNISINOS, 2007. n. 3.

. Teoria geral do delito e da imputação objetiva. 3. ed. São Paulo: Atlas, 2014.

DEZALAY, Yves; GARTH, Bryant. Dealing in Virtue: international commercial arbitration and the construction of a transnational legal order. Chicago: University of Chicago Press, 1996.

DÍEZ RIPOLLÉS, José Luis. El Derecho Penal simbólico y los efectos de la pena. Boletín Mexicano de Derecho Comparado, año XXXV, núm. 103, enero-abril de 2002, pp. 63-97. Disponível em <http://goo.gl/UmH9ha>. Acesso em: 23 abr. 2014.

DONALDSON, Ken; BORM, Paul. Particle toxicology. Boca Raton: CRC Press, 2007.

DUARTE, Edson. Projeto de Lei da Câmara n. 5076, de 2005. Dispõe sobre a pesquisa e o uso da nanotecnologia no país, cria Comissão Técnica Nacional de Nanossegurança - CTNano, institui Fundo de Desenvolvimento de Nanotecnologia - FDNano, e dá outras providências. Disponível em: <http://goo.gl/imUvt1>. Acesso em: 26 mar. 2013.

ENGELMANN, Wilson. O diálogo entre as fontes do Direito e a gestão do risco empresarial gerado pelas nanotecnologias: construindo as bases à juridicização do risco. Constituição, Sistemas Sociais e Hermenêutica: Programa de Pós-Graduação em Direito da UNISINOS: mestrado e doutorado, Porto Alegre; São Leopoldo, p. 319-344, 2012.

FEDERAÇÃO DOS TRABALHADORES DO RAMO QUÍMICOS DA CUT DO ESTADO DE SÃO PAULO (FETQUIM-CUT). Termo Aditivo à Convenção Coletiva de Trabalho FETQUIMCUT 2012/2013, de 19 de abril de 2012. Setor Farmacêutico. Disponível em: <http://goo.gl/YxqmMM>. Acesso em: 30 set. 2014.

FELDENS, Luciano. A constituição penal: a dupla face da proporcionalidade no controle das normas penais. Porto Alegre: Livraria do Advogado, 2005.

FEYNMAN, Richard. Há mais espaço lá embaixo. Tradução de Roberto Belisário e Elizabeth Gigliotti de Sousa. Revista Parcerias Estratégicas, Brasília, n. 18, p. 137-155, 2004. 
FIORINO, Daniel J. Voluntary initiatives, regulation, and nanotechnologies oversight: charting a path. Project for Emerging Nanotechnologies, n. 19, nov. 2010. Disponível em: <http://www.nanotechproject.org/process/assets/files/8347/pen-19.pdf>. Acesso em: 30 set. 2014.

FREITAS, Vladimir Passos de. A contribuição da Lei dos Crimes Ambientais na defesa do meio ambiente. Revista CEJ. Brasília, n. 33, p. 5-15, 2006.

GARCÍA ARÁN, Mercedes. Remisiones normativas, leyes penales en blanco y estructura de la norma penal. Estudios Penales y Criminológicos. vol. XVI. Santiago de Compostela: Servizo de Publicacións da Universidade de Santiago de Compostela, 1993.

GILISSEN, John. Introdução histórica ao Direito. Tradução de Antonio Manuel Hespanha e L. M. Macaísta Malheiros. 2. ed. Lisboa: Fundação Calouste Gulbenkian, 1995.

GRECO, Rogério. Curso de Direito Penal: Parte Geral. 2. ed. Rio de Janeiro: Impetus, 2003.

INTERNATIONAL ORGANIZATION FOR STANDARDIZATION - ISO. International Standards and "Private Standards". Genève, 2010. Disponível em: <http://goo.gl/tpSwPS>. Acesso em: 21 maio 2013.

. ISO Membership Manual. Genève, 2013. Disponível em: <http://goo.gl/CGmvqC>. Acesso em: 21 maio 2013.

2012.

Standards catalogue. 2005. Disponível em: <http://goo.gl/B7tVxc>. Acesso em: 23 nov.

LUHMANN, Niklas. Los derechos fundamentales como institución: aportación a la sociología política. Tradução para o espanhol de Javier Torres Nafarrate. México: Universidad Iberoamericana, 2010.

MAYNARD, Andrew. Nanotechnology and occupational health, [S. 1.], 2005. Disponível em: <http://epa.gov/ncer/nano/lectures/maynard_06_13_05_presentation.pdf>. Acesso em: 30 set. 2014. Palestra publicada no site da EPA, no hyperlink Nanotechnology: Lectures.

MELO, Celso Pinto; PIMENTA, Marcos. Nanociência e Nanotecnologia. Revista Parcerias Estratégicas, Brasília, n. 18, p. 9-21, 2004.

NANOTECHNOLOGY. Consumer Products Inventory: Analysis. [S. l, S. d.]. Disponível em $<$ http://www.nanotechproject.org/inventories/consumer/analysis_draft/>. [201-a]. Acesso em: 30 set. 2014. Matéria divulgada no site Project on Emerging Nanotechnologies, no hiperlink Inventories: Analysis.

[S. l, S. d.]. Disponível em <http://www.nanotechproject.org/inventories/consumer/>. [201-b]. Acesso em: 30 set. 2014. Matéria divulgada no site Project on Emerging Nanotechnologies, no hyperlink Inventories.

NEL, Andre; XIA, Tian; MADLER, Lutz; LI, Ning. Toxic potential of materials at the nanolevel. Science, Washington DC, v. 311, n. 5761, p. 622-627, 3 fev. 2006. 
OBERDORSTER, Gunter; OBERDORSTER, Eva; OBERDORSTER, Jan. Nanotechnology: An Emerging discipline evolving from studies of ultrafine particles. Environmental Health Perspectives, Washington DC, v. 113, n. 7, p. 823-839, jul. 2005.

PÉREZ CEPEDA, Ana Isabel. La seguridad como fundamento de la deriva del derecho penal postmoderno. Madrid: Iustel, 2007.

PRADO, Luiz Regis. Direito penal do ambiente: meio ambiente, patrimônio cultural, ordenação do território, biossegurança. 2. ed. São Paulo: Ed. Revista dos Tribunais, 2009.

QUEIROZ, Paulo. Curso de Direito Penal: parte geral. 9. ed. Salvador: JusPODIVM, 2013.

RAMOS, Luiz Rodríguez. Compendio de Derecho Penal. Madrid: Trivium, 1986.

SARNEY FILHO, José. Projeto de Lei da Câmara n. 5.133, de 2013. Regulamenta a rotulagem de produtos da nanotecnologia e de produtos que fazem uso da nanotecnologia. Disponível em: <http://goo.gl/6sIYFa>. Acesso em: 30 set. 2014.

SCIULLI, David. Theory of Societal Constitutionalism. Cambridge: Cambridge University Press, 1992.

SESSANO GOENAGA, Javier Camilo. La protección penal del medio ambiente. Pecualiaridades de su tratamiento jurídico. Revista electrónica de Ciencia Penal y Criminologia. n. 4, vol. 11, 2002. Disponível em: <http://criminet.ugr.es/recpc/recpc_04-11.pdf>. Acesso em: 22 mar. 2015.

SILVA, Guilherme Frederico Bernardo Lenz. Nanotecnologia: avaliação e análise dos possíveis impactos à saúde ocupacional e segurança do trabalhador no manuseio, síntese e incorporação de nanomateriais em compósitos refratários de matriz cerâmica. 2008, 73 f. Trabalho de Conclusão do Curso de Especialização em Engenharia de Segurança do Trabalho, Universidade Federal de Minas Gerais, Belo Horizonte, MG, 2008. Disponível em: <http://goo.gl/IzPjaf>. Acesso em: 30 set. 2014.

SILVA, José Afonso. Direito ambiental constitucional. 4. ed. rev. e atual. São Paulo: Malheiros, 2002.

SILVA SÁNCHEZ, Jesús-Maria. La expansión del Derecho penal: aspectos de la política criminal en las sociedades postindustriales. Madrid: Cuadernos Civitas, 1999.

TEUBNER, Gunther. A Bukowina Global: sobre a Emergência de um Pluralismo Jurídico Transnacional. Tradução: Peter Naumann. Revisão técnica: Dorothee Susanne Rüdiger. Impulso, Piracicaba, v. 14, n. 33, p. 9-31, 2003.

El derecho como sistema autopoiético de la sociedad global. Tradução para o espanhol por Manuel Cancio Meliá e Carlos Gómez-Jara Díez. Peru: ARA, 2005.

THE ROYAL SOCIETY. The Royal Academy of Engineering. Nanoscience and nanotechnologies: opportunities and uncertainties. Londres, jul. 2004. Disponível em: <http://goo.gl/h1uTsW>. Acesso em: 30 set. 2014. 
UNITED STATES ENVIRONMENTAL PROTECTION AGENCY. Nanotechnology white paper, Washington DC, fev. 2007. Disponível em: <http://goo.gl/GyDi3b>. Acesso em: 30 set. 2014.

VIANA, Tião. Projeto de Lei do Senado n. 131, de 2010. Altera o Decreto-Lei no 986, de 21 de outubro de 1969, que institui normas básicas sobre alimentos, e a Lei ${ }^{\circ} 6.360$, de 23 de setembro de 1976, que dispõe sobre a vigilância sanitária a que ficam sujeitos os medicamentos, as drogas, os insumos farmacêuticos e correlatos, cosméticos, saneantes e outros produtos, e dá outras providências, para determinar que rótulos, embalagens, etiquetas, bulas e materiais publicitários de produtos elaborados com recurso à nanotecnologia contenham informação sobre esse fato. Disponível em: <http://goo.gl/5MXuQB>. Acesso em: 26 mar. 2013.

WERMUTH, Maiquel Ângelo Dezordi. Medo e Direito Penal: reflexos da expansão punitiva na realidade brasileira. Porto Alegre: Livraria do Advogado, 2011.

ZAFFARONI, Eugenio Raúl. Em busca das penas perdidas. 5. ed. Rio de Janeiro: Revan, 2001.

; PIERANGELI, José Henrique. Manual de Direito Penal Brasileiro: Parte Geral. 2. ed. São Paulo: Revista dos Tribunais, 1999.

ZAFFARONI, Eugenio Raúl. O inimigo no direito penal. Trad. Sérgio Lamarão. Rio de Janeiro: Revan, 2007.

ZÚÑIGA RODRÍGUEZ, Laura. Política criminal. Madrid: Colex, 2001.

\title{
NANOPARTICLE POLLUTION, ENVIRONMENTAL CRIMINAL LIABILITY AND LEGALITY PRINCIPLE: REFLECTIONS ON THE COMPLEMENTATION OF THE UNREGULATED CRIMINAL NORM IN ENVIRONMENTAL CRIMES ACT
}

\begin{abstract}
This article addresses the issue of environmental criminal liability related to pollution by nanoparticles, faced to the shortcomings that Environmental Crimes Act (Brazilian Law \# 9.605/1998) presents when faced to the complexity raised by this question - which is revealed, particularly, in the fact that, being configured as unregulated criminal norm, article 56 and following of the mentioned Act require supplementation by other sources. However, there is still no rules in Brazil that address nanotechnology risk, which evokes this research problem: is there any possibility for this complementation through norms elaborated by other bodies, diverse from Legislative branch - i.e. the regulatory state agencies or even non-governmental institutions that emerge in today's global legal pluralism? Hypotheses presented throughout the text do not neglect the fact that enabling the completion of unregulated criminal rules by the aforementioned legal pathways may represent an intolerable ease against fundamental guarantees provided to citizens by a pattern of Criminal Law typical of a Democratic State under the rule of law - particularly with regard to the legality principle. The purpose is, therefore, to reflect about the very effectiveness of environmental criminal law before degradation scenario resulting from indiscriminate release of nanoparticles, demonstrating that, in such cases, environmental protection could be achieved at higher levels of effectiveness through civil, administrative, and criminal alternative penalties, reaffirming, reflexively, the idea of subsidiarity of State's jus puniendi.
\end{abstract}

KEYWORDS: Environment. Nanotechnologies. Criminal Law. Unregulated criminal norm. 
POLUIÇÃO POR NANOPARTÍCULAS, RESPONSABILIDADE PENAL AMBIENTAL E PRINCÍPIO DA LEGALIDADE: REFLEXÕES ACERCA DA COMPLEMENTAÇÃO DA NORMA PENAL EM BRANCO DA LEI DE CRIMES AMBIENTAIS

Recebido: 7 de abril de 2015

Aprovado: 25 de maio de 2015 